\title{
What Makes Annual Conferences Special?
}

\author{
Prepared by Denise L. Rode
}

NODA conferences have informed and inspired participants for more than 50 years. Whether it's their first conference or their 21st, NODA members describe their conference memories with heartfelt words. Here is just a sample of favorite recollections of past and present NODA leaders when asked what makes NODAC so special:

Victor K. Wilson (College of Charleston): "I remember my very first NODA conference in 1984. The first person who introduced herself was Val Hodge (former NODA leader, now deceased). That was the beginning of an extremely special NODA relationship and personal friendship. I also remember the 1996 conference, when I was finishing my term as President. I was told that the executive suite we were using had been requested by Diana Ross and she had to be told no. Talk about feeling special!"

Brenda McKenzie (Kent State University): "My first NODA conference was in Hartford, CT as a graduate student. I don't remember much from the sessions (that was a very long time ago!), but I do remember feeling welcomed and energized. NODA has become my professional development home. I have had some of my best, most challenging opportunities through NODA, including co-hosting the 2001 annual conference in Toronto."

Michele (McManus) Howard (University of North Carolina - Charlotte): The Traverse City conference (1989) was certainly memorable in that we experienced four distinct seasons during the meeting - warm and sunny when we arrived, the fall chill set in soon after, then a small tornado hit the area, and by the conclusion of the conference, snow falling. The San Francisco earthquake also occurred during this time, and I distinctly remember the care and concern demonstrated for our colleagues from the Bay area, especially for Sister Clare Wagstaff (now deceased).

Beth Lingren Clark (University of Minnesota): "My first conference was as a graduate student in Minneapolis in 1995. I remember how overwhelmed I was, and how impressed I was by the conference and the people I met. Over the past 12 years, I've found that my NODA colleagues rejuvenate me, validate my concerns and issues, and support me." 
Lucy LePeau (University of North Carolina - Charlotte): "My first NODAC was in Toronto in 2001 (shortly after 9/11). Being in Toronto was a nice introduction to the international growth of the orientation profession. I remember sitting at the opening banquet and wondering, 'How can I get involved with this organization?' Each year (at the conference) I am struck by the commitment of the students and professionals toward enhancing what we do to meet the needs of incoming students and their families."

Dian Squire (University of Maryland - College Park): "My first NODA conference experience was attending the Orientation Professionals Institute (OPI) in Salt Lake City (2006). As I walked around the hotel lost, I was stopped by various NODA Board members who were very friendly and got me to the right place. I was nervous walking into the room because I missed the first night of OPI, but I met a few people that day and when we all went out that night, we really bonded. My OPI cohort is now the support network I turn to whenever I have questions related to orientation."

Gregory Wolcott (University of San Francisco): "My best NODA conference was my first. I was a new professional and attended the first-ever Orientation Professionals Institute. It was a great way to meet people who were like me-just starting in the field and totally excited to be an orientation professional. I bonded with several of the OPI participants, many of whom are the friends I hang out with at every NODA conference since. We also developed a strong bond to our OPI mentors, one of whom was the inspirational and fun-loving Val Hodge."

Melvin McBean (University of Illinois - Chicago): "My first impression of NODA was formed at the 1998 conference in Austin. I recall standing in the huge foyer of the Renaissance Hotel during the regional reception, sipping fruit punch and making small talk with an equally enthusiastic first-timer. I knew I would like this association. My most unforgettable NODA moment occurred in Toronto on November 3, 2001 when Beth Lingren and I were awarded the bid to host NODAC 2004 in Chicago. I was filled with excitement, jubilation, and nervousness."

Carren Martin (University of Wisconsin - Madison): "I attended my first annual conference as an undergraduate in 1992. I remember being overwhelmed by the number of people and the variety of activities and sessions. At the same time, I felt instantly comfortable and welcomed. The opportunity to interact with so many people dedicated to new student orientation had a major impact on my career. Since then, I've accumulated many miles of air travel (and several pieces of battered luggage) traveling to NODA conferences and meetings, and I treasure every opportunity."

Harrison Greenlaw (University of South Carolina): "At my first conference, I was greeted by board members from my region who made me feel welcome. Since then, I've tried to help new members acclimate to NODAC as I always appreciated those who helped me in that way. Other conference memories include assisting 
with a pre-conference workshop in Arizona in 1985 where the computers didn't work for the first 20 minutes, and serving on a panel where one member spent much of the session time discussing personal problems at length. I enjoy meeting former graduate assistants at NODAC and seeing them become successful professionals. There are also camaraderie and wonderful learning experiences by serving on national conference committee and as a regional coordinator."

Abbey Wolfman (Northern Illinois University): "My first annual conference was in 2005 at Miami. I was excited to be surrounded by so many passionate and energetic professionals, and left feeling refreshed and happy to be working in orientation. I remember most fondly my OPI experience last year in Salt Lake City (2006), where I met a group of eight people who communicate weekly. It's great to have a support group of new professionals who understand me and my work."

\section{Memorable Speakers, Special Events, and Side Trips}

Denise Rode (Northern Illinois University): "My passion for working with students began when I heard L. Lee Knefelkamp, Judith Prince, and Ted Miller speak at NODAC 1979 in Washington, DC. For the first time, I was exposed to student development theory, and I was hooked. My career and my doctoral dissertation topic took shape at that conference. I also remember being inspired by the sessions led by M. Lee Upcraft and John N. Gardner at the 1993 conference where NODA's first monograph was unveiled."

Lucy LePeau: "My favorite keynoter was Paul Wesselman in Chicago (2004). I'd heard him at a regional conference and thought it was fantastic that he was spreading his message of 'the ripple effect' to others around the country."

Harrison Greenlaw: "I recall taking the ferry to Catalina Island and seeing waterfalls in Washington state along the Columbia River (2003)."

Carren Martin: "Sally Karioth (Savannah, 1993) stands out in my mind as an outstanding speaker. She was a nurse who talked about making a difference in the lives of others. Though her background was in health care, her message really resonated with our audience."

Victor Wilson: "One of the funniest moments of any NODA conference happened during the 1998 conference when Dan Robb (NODA President at the time) came to the Awards Luncheon wearing a hotel bathrobe and shower cap. It was a priceless moment that only Dan could pull off."

Brenda McKenzie: "Some of the speakers I remember most are Dr. Susan Komives (of the University of Maryland), motivational speaker Nancy Hunter Denney, and the director of Habitat for Humanity who spoke at the Providence 
conference (1990)."

Michele (McManus) Howard: "The Tampa (1999) conference was very meaningful for me since my dear colleague and friend, Margaret Anliker, was scheduled to be the conference host. Two years before "her" conference, Margaret was killed in a automobile accident, yet the meeting reflected her memory and spirit through the "Pearls of Wisdom" cards distributed at the opening session. Margaret would have been incredibly honored and proud of the hard work and dedication of her colleagues who hosted the conference. It was a wonderful example of the compassion, teamwork, and care that make NODA a wonderful professional association." 